\title{
Human Body, Consciousness and Identity in the Mirror of Life Interviews with Female Coaches
}

\author{
Ilona Bodnár
}

Semmelweis University Faculty of Physical Education and Sport sciences, Budapest, Hungary

ABSTRACT

\begin{abstract}
One of the recurring themes when conducting life-interviews with women coaches is their confrontation with the fact that their physique does not correspond to the body-frame considered to be ideal in their respective sports disciplines. Since they can preserve their athletic identity only with the help of their physique, the course of their careers depends on the solution they find to this problem. The study presents this decision-making process using Luhmann's systems theory: as an environmental interaction between a neurophysiological (the body), a psychological (the identity of women coaches) and a social (sports) system. It looks upon this situation as a communication between female athletes and competitive sport as a social system, in which observation is accorded an outstanding role. Assuming the role of an observer, female athletes see the series of movements and solutions that their coach does not recognize. Instead of physical perfection, they develop the individual perfection of movement execution.
\end{abstract}

KEYWORDS gender, lifespan, narrative interview, Luhmann theory

\section{Introduction}

It was not only my own research that inspired me to write this study, but also those sport sociologists who believe that the (athletic) body is an outstandingly important research subject. As Eichberg (1995) put it: the social story of the body is the area where sport sociology can conduct basic research. He considers the "third way" approach of Scandinavian sociology to be worth following, which, besides being centred on the body, is characterized by a richness of links: between fields of science; different areas of research; qualitative and quantitative research methods (Eichberg 1994). Giulianotti (2005) reiterates the persuasive nature of these views looking back from a perspective of ten years. In the closing chapter of his book on the body he offers the body as a topic of research for those missing wider professional attention, but only with an interdisciplinary perspective and with the use of new and bold research methods.

The primary objective of my research was to study in my country the coach's profession as a female career path. I was curious to see how successful women coaches define and build their professional identity and to see if there are any commonalities between the individually developed professional practices. I aimed to do this without influencing or orienting their thinking even a little 
bit, thus I chose the method of the narrative interview and life history (N=14)-(Bodnár 2003, 2006). This method concerns studying identity, because it reflects the continuous dialogue conducted by the individual with him/herself and with the environment. My case also turned out to justify the remark in methodology manuals (Andrews, Mason and Silk 2005) highlighting the fact that narrative interviews are especially useful in cases where we wish to discover identities that previously have not been researched.

At the same time, this study is a good example of how certain topics might surface in the narrative, in a way that the researcher would not have thought of beforehand. In the case of female coaches, their relation to their bodies and to the body-frame considered to be ideal in their respective sports disciplines turned out to be such a topic. Since their height and body complexion were slightly different from what was expected by the profession, they were increasingly compelled to comply with these expectations. Their experiences gathered as competitive athletes and as a result of a conscious management of their bodies not only influenced their athletic careers, but later on also impacted their approach as coaches.

\section{Theoretical framework}

I found guidance in three publications on how to untangle the interrelated elements of the interview texts. These publications worked as a set of gears and thus started my train of thought and the stories of the female coaches. Their intellectual energies boosted both, but at the same time also linked the contents of the two consciousnesses. I have to mention Eichberg in the first place, whom I have already quoted above. He drew attention to a more differentiated body treatment and classification compared to the discipline-based approach of Foucault (1990). He is of the opinion that beside the disciplined - streamlined and healthy - body, the grotesque body described by Bakhtin (1982) is also present nowadays. He relied on the dialogical philosophy of Buber (1991) for the study of body cultures concurrently present in society. He applies the Buber-triangle signifying the three dimensions of human existence: the three tips of the triangle of body-awareness represented by the Ibody, the Thou-body and the It-body (Figure 1).

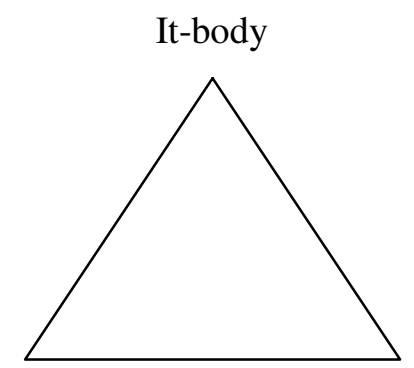

I-body Thou-body

Figure 1. The dialogical triangle of body awareness (Eichberg 1994, p. 110)

Taking into account its subjectivity, Eichberg considers the study of the I-body to be possible using an introspective method: through the analysis of curriculum vitas and memoirs with qualitative methods. The objective It-body is in the empirical domain: it is measurable and observable for science; quantitative data on it may be collected. In the interview texts the body picture female coaches created of themselves is the I-body, whereas the views on the ideal body for their sports discipline constitute the It-body. They compare the internal picture with the description that their environment deems to be 
objective. The third element of the triad is not the Thou-body formulated by Eichberg, but instead it is a person, the coach. Together with the changes necessitated by the interviews it became possible to analyze the relations between these three using the structural balance theory (Szántó 2006). This social psychology theory developed by Heider studies the relations existing between two social actors and a non-personified entity, which can be both positive and negative. A triad will be imbalanced, unstable if the count of negative relations yields an uneven number. The story told by the female coaches shows that an unbalanced state of relations came into existence when, with the passage of time during their competitive careers, they could no longer meet the expectations based on the accepted body-image in their sports discipline. The relation which was positive until then, turned negative. This tilts stability because the coach, representing the profession and the sport culture, remains committed: for the coach the ideal body remains a precondition for success and results.

When studying the balancing solutions of female coaches it was found that the reasons and explanations go beyond this trilateral relation: competitive sport as a system should also be drawn into the scope of the analysis. It was Luhmann's theory of the functioning of social systems that provided the framework into which I could fit this equilibrium problem (Luhmann 1995, 2006). The article by Tangen (2004) was crucial in making the selection: he looks upon recreational sports, recreation itself, as a peculiar social system, where communication takes place between the individual, the different sport disciplines, the equipment and the venues. The most important components of this dialogue are the expectations embedded in the prescribed forms of movement, which are coercive in nature.

Our choices concerning the pursuit or the non-pursuit of sports activities is in effect a decision about wanting to meet the challenges posed by these expectations or not. Expectations we sense define the interpretation of the given situation and thus the resulting action. Female coaches have to decide whether they consider the challenges of the ideal body to be justifiable or not, and if yes then as a result of their decision, they will have an expectation of the expectation come about, consequently, they will want to satisfy this, that is in turn, satisfy themselves. With their reflections, they continue the communication between themselves and the system, meaning that they continue to stay within the sport. They remain where the objective of the organized competition - the function of the system, according to which it distinguishes itself in society - is victory, declaring someone a winner once the contestants have fought the competition. Winning first place depends on the performance capability of the body, but execution of movement - in the way prescribed by the rules of the sport - in an approved way is a basic requirement. Anyone not learning or not adhering to the forms of movement deemed to be acceptable in the given sports discipline cannot call him/herself a competitive athlete and may not enter the competition. Consequently, people for whom becoming a competitive athlete is a central part of their personality will do everything for their bodies and with their bodies, because it is the most important asset they have in their process of self-assertion. They can only establish and preserve their identity as a competitive athlete with the help of their bodies. Speaking at the systems level: the discussion will be about the environmental interrelation of a neurophysiological (the body), a psychological (the identity of female coaches) and a social (the sport) system.

\section{Body - consciousness - identity}

Besides drawing up the theoretical framework, a few definitions also ned to be in place, because differentiation between these three interrelated notions - body scheme, body image and body awareness - is not evident even in professional literature. I will follow the approach of Kudar, because not only did she conduct body image studies on competitive athletes, but in her work she also follows the evolution of the interpretation of these notions (Kudar 1994). The body scheme is the scheme generated in the central nervous system about the body, its dimensions, limits, proportions, which is of 
primary importance in general orientation in space and in the organization of movement. It is neurophysiological organization, which does not contain any consciousness, any cognitive elements. Basically the body scheme is reflected in the athletic It-body objectively defined by sport science because it can be measured and translated into numbers. When such biological sensation is supplemented by cognitive elements, that is when it transforms into a social construction, we talk of body image: a complex experience about our body, which contains information related to the body scheme and the psychosocial factors alike. The positive and negative experiences of the individual about the body, the individual's attitude and the norms set by the environment all have an impact on this mental representation. This is the level where reciprocity appears with mutual impacts: a dialogue between the body and the consciousness, the individual and the environment and the different fields of science (i.e. psychology, philosophy and sociology). Psychology also emphasizes the sociability of the concept that it is impossible to establish and maintain our own body image without the feed-back of the environment (Schilder 1978). The socializing effect however is not only important for reflection, but also functions as reference: solution methods, the way people around us use their bodies, have a significant influencing impact. It is on the level of the body image that expectations arise, the need of compliance, the desire of a formable body because we look upon ourselves as an external observer. Bourdieu (1978) calls this social consideration, the strength and efficiency of which depends on how much the person towards whom this is directed is aware of the body categories deemed to be desirable; to what extent the (sub)culture constitutes a part of his/her life; to what extent he/she is committed in this direction. The extent of this defines to what extent a person considers the (body) behaviour considered by the given environment to be legitimate and exemplary to be worth following and to be mandatory.

The complete linking of the material and the intellectual sphere can be observed on the level of body awareness: the conceptualization of body experiences, which is based on consciousness experiences gained about our body and the analysis of information from different sources. The impact of body awareness on self-awareness, the importance of somatic experiences, are emphasized in an expression which in the professional literature is often used instead of 'body': "embodiment".

This approach to embodiment is testament to the fact that the significance of body-related experiences has increased in terms of the individual, the community and culture. Knowledge gathered this way plays a decisive role in forming and maintaining identity, because self-awareness no longer means only the entirety of our knowledge about our mental status, but also comprises consciousness awareness of our physical status. According to Giddens (1991) the body is not only an expression of our body, but is also a tool for forming it. In the process he calls the identity project the transformations and changes occurring in and on the body also lead to modifications in identity. The relationship between the two entities is not hierarchical but dialogical.

In this short overview, I wanted to show - among other things - how other researchers see what Luhmann (1995) describes: that intellectual, psychical and social systems always presuppose themselves as a necessary environment and come into existence through joint development. The same environmental necessity and interrelation exists between the body, as an organic system and the identity, as a psychical system. It is much easier to analyze this interrelated links in an area where the body has an evidently outstanding role. One of these is sport.

\footnotetext{
${ }^{1}$ Tangen (2004) emphasizes the role of movement as the linking element between body and the consciousness, when he introduces the notion of embodied knowledge, which refers to the somatic aspect of knowledge. In the body, most of the time it is about unconsciously accumulated knowledge, which refers to the execution expected by the environment. This is the ability of action, the ability of movement, which the consciousness will use as an unconsciousness asset, which in everyday language is called practical gift.
} 


\section{The ideal body}

Body image as a social construction is used by groups as a criterion for inclusion: the body shape considered to be legitimate allows boundaries to be drawn and differentiation to exist. The individual does nothing else in the interest of the desired acceptance, but keeps comparing his/her body image with the one considered to be ideal by the community and if any differences are found, tries to eliminate these (Kende 2002). The initial construction of the body image in different sports disciplines is based on the coach's experiences. The coach will use his/her own athletic past and the athletes he/she trains to compose the ideal, an important element of which will be "good movement". It is based on individual experiences, on having a "good eye" - the strength of the look. Thus it also includes a great deal of subjectivism. With the spread of competitive sports, the It-body of a given sports discipline will become more objective, which on the one hand is related to uniform training methods, and on the other hand to the introduction of new fields of science. Objective research "translates" the image of the It-body to the language of numbers, measurability and comparability. The ideal body becomes a scientific tool for selection and also plays a role in reducing risk factors in the interest of more predictability in preparation.

Domestic talent searching has shown that the ratio of inherited characteristics and environmental impact in sports is 70:30 (Harsányi 2000). Inherited characteristics can be classified into two groups: body anatomy and motor abilities. The measurable data derived from these provide the so-called selection indicators. ${ }^{2}$ These look upon the athlete in a non-personal way, like an object, as being something required in order to achieve the maximum results (Eichberg 1995). They try to disregard the difference between the It-body and the I-body. The body is not an independent, organic system but an intellectual construction, a part of sports as a social system. We can look upon it as the result of the self-creation, the theoretical construction, the intellectual gain of sports science. Contrary to this, the I-body is a living neurophysiological system, which is the "environment" for a psychical system, the identity. This existing body always exists with an independent consciousness, a personality.

The-body, that is, the disciplinary force of the system becomes more and more evident when we move upward. The performance principle, competition and the comparison with others appear alongside the joy felt at learning and acquiring a new movement, which plays an important role in the development of a child's personality. The introduction of the principle of efficiency causes the emphasis to shift from the I-body to the It-body. The emphasis is not transferred but shifts: this is a process in which it is difficult to find milestones, because it changes with every individual and every sport. In this new system of relations the athlete experiences a situation of dual-dependency: in the interest of achieving success the athlete has to subordinate him/herself, his/her I-body to the methods of the coach on the one hand and the prescriptions of the It-body on the other hand. The coach's experience and the authority of science not only develop muscle mass, the body shape, but because of the dialogical nature of the body and the consciousness, they also develop the personality. While the prescriptions and expectations related to the It-body are well defined in professional literature and thus are evident, there are embedded expectations aimed at the personality, which are implicit in nature and not openly articulated. These are to be included among evident expectations, they are an auxiliary part, but just as important in regulating behaviour (Tangen 2004). For decades the sports lobby was able to

\footnotetext{
${ }^{2}$ Over time psychological and social elements are also included in the selection process, aimed at securing the necessary supply of new talent, but these can only be elements that can be studied with a standardized, questionnaire method. Thus we cannot say that the scientific net, woven thicker and thicker would take the individuality of the personality into account better or that it would be more lenient. The system itself has the inherent need to take individuality into account to some extent: it uses functional experience when widening the methods of selection used, because among other things it provides for its survival, its further existence with this.
} 
assert its interest in ensuring that journalists and researchers only dealt with the positive aspects of psychological duress. Papers first appeared in the 1970s which beside the physical threats also called attention to the emotional threats that athletes have to endure: namely the endeavours of the system to homogenize the individual (Shogan 1999). ${ }^{3}$ The system also composes the ideal It-body personality.

\section{Communicating the expectations of the It-body 4}

When responding to my opening sentence, "Please tell me about events, experiences in your life which are important for you as a coach", all of my interviewees mentioned their athletic careers. They highlighted two moments from this period of their lives: the selection of the sport to be pursued, the start of regular sports activities and their negative experiences, their struggles. The role model of a coach - since it is a profession build on practical experiences - has, as a basic precondition a past in competitive sports, the length and quality thereof. The starting phase, the moment of entrance is important because the knowledge gathered in the period since means justification. It meant just this at the start of the coaches' career and also during the moments of the life interview. This is the reason for a detailed explanation of the starting moments. All of them were good, the majority of them excellent athletes, but their results were important at the outset of their careers, when they were given a chance to start practising the profession (Bodnár 2006). During the pursuit of their careers their competitive successes became more and more "bygone", whereas the elements of the competitive career that can be used in everyday life gained more importance: thus these are what mainly appear in the narrative of the present.

Among these are the struggle-stories of the competitive sports life period, organized around the body.

"I always had a feel for it, I am small but I always had a feeling for the ball, always being there where the ball was. But I always had to struggle for this, because of my size."

"Goalkeepers are always better thinkers; they are more clever-minded. You see, I am not $2 \mathrm{~m}$ tall. I weighed a good 56 kilos then, I was very loose, lithe, that is I had it all, except for the $5 \mathrm{~cm}$ that I lacked in height. I had to make up for this with clever thinking, being the very consciousness goalkeeper that I was. I am sure that because of this I spent much more time thinking while playing handball."

"...but I did not grow tall enough. I owe it to the variety of sports that as a competitor I persevered tirelessly and had a developed muscle structure."

"I was a very good rower, but I was such a skinny little girl that they gave me extra injections. [...] I really had the will, and it is this, this will, that one looks for in one's athletes."

"You touched my sorest spot. We had been frustrated for years with K.K., that we were the smallest."

These struggles are in essence the communication between the interviewees and sport as a

\footnotetext{
${ }^{3}$ Artists have again drawn attention to the alienating effect of sports earlier. I quote two British films as examples: The Loneliness of the Long-distance Runner (Tony Richardson 1962) and This Sporting Life (Lindsay Anderson 1963).

${ }^{4}$ In the following parts of the study I use the systems theory of Luhmann $(1995,2006)$ for the analysis of the interview texts (I do not discuss the theory itself, since my objective is only its application). Since I continuously construct the explanations according to the above mentioned book, for this reason I will not reference it hereafter.
} 
social system. The subject of this is the negative difference between the I-body and the It-body, to noncompliance with expectations about the ideal body. The warning about the difference is the expert eye's first fleeting perception. According to objective views the It-body functions as a machine and if the appropriate (training) method is applied, its efficiency can be increased. The purpose of training is to develop the body in such a way that it should be able to achieve maximum performance. The primary criteria in selection are body dimensions, the anthropometric characteristics. These cannot be developed at all or - as was the case with the body of one of the interviewees - can only be developed in a very restricted manner, because the openness of organic systems to the environment is restricted. The sports system communicates what constitutes the highest risk factor for functioning, for survival: height and body dimensions differing from the ideal decrease the chance for the expected performance, for victory. Achieving the essential element of competitive sport might be in danger. For this reason, female athletes are declared paradox on the basis of their non-compliance: they want to exclude them from participation in operations of the system, from higher level competition, from advancement.

Who communicates all this? It is no coincidence that the texts do not mention a person. Knowledge about the ideal physique forms the basis of a given sport's culture. It circulates in the system. On the one hand the system expects this to be known: it poses this to the individual as a precondition for commitment, considering its existence as an acceptance of the expectation. On the other hand this circulation also means that the information and communication are continuously present, but their unity will only come about if the athlete understands them. In our case this moment occurs when the future of the female athlete's competitive career is questioned: the former, the past does not necessarily lead to the latter, the future. Understanding the expectation becomes an event and brings about a differentiation in time, emphasizing the present.

Female coaches were first confronted with this problem in their adolescence. ${ }^{5}$ (Selection did not occur at such an early age in sport as it does nowadays). We are talking about teenagers who have a sports past, which at this stage now also results in emotional commitment and objectives. These life objectives are none other than expectations from us, thus these also have a direction and strength, just as the It-body expectations that are directed towards the individual. Their reaction is influenced by the presence of the strength they get from winning competitions and whether their identification with the existence of a competitive athlete is a central element of their identity or not. The struggle shows that they have made these decisions and a sign of being different is a danger to just these ideas. Add to that the fact that adolescents are very sensitive to criticism of their personalities, interpreting it as a sign of complete rejection. At the same time it is thanks to the relatively developed nature of their personalities that they are capable of articulating an independent response. Leaving behind childhood dependence, they wish to show adults what they are capable of alone in as many situations as possible.

\section{I can see what my coach does not see ${ }^{6}$}

Female coaches can provide two types of responses to the expectations that endanger the ideas they have about their future: they can accept them and thereby signal that they find these justifiable, or they can reject them. This decision shows the intent to maintain or terminate communication, which also means that they wish to continue to function as part of the system or they wish to leave. They decide on providing a response, they develop reflective expectations towards themselves. Thus the

\footnotetext{
${ }^{5}$ Even earlier there were control points in the functioning of the system, when selection was based on certain distinct abilities, but female athletes complied with these, thus these were not turning points in their life stories.

${ }^{6}$ Reference to the work of Luhmann (1999): I can see, what you cannot see.
} 
external force becomes an internal driving force, to which they attach their own interpretation of content. This decision is also a step in the direction of having a better integrated personality.

What can they rely on when seeking a solution? Their own past and their experiences. Reaching adolescence is also important because thanks to their sporting past they can recall experiences to a greater extent; their repertoire of action is wider in scope. Taking into account the requirements of the system, the It-body, they can demonstrate their repertoire of movement, their movement culture, the hereditary factor that is the second most important according to the selection method. They draw on the ability that has helped them so far, that was acknowledged by the system so far. This was the positive feedback that brought about the emotional link, which can mobilize reserves, which motivates female coaches to show that their bodies are suitable for the next level of the competitive system.

"Practically these basic capabilities of speed, a lithe body, flexibility and endurance were the ones that I took with me from athletics, but in retrospect, looking at it with my present mind, I would never have made a top ranking athlete, never in my life. I did not have all the characteristics needed for world level results."

"I started out as a coach mixing the basic elements of three sport disciplines, because I pursued athletics very intensively, I also made them do a lot of athletics. In basketball again, you have the need of positioning. I learnt this from there, while I transferred the importance of technique from tennis."

In this new situation one of the most important activities of the interviewees was observation, in its primary and secondary forms alike. Their first step is self-observation, within which we can distinguish between two series of differentiation. I have already mentioned the first: they identify using their repertoire of movement, they tag the forms and methods of execution which they might have adapted from other sports, but precisely because of the role of movement acting as a medium, they can also put this to use here. We could also say that they use the points of reference taken from the system to differentiate elements that might be useful later: looking from the perspective of the future they are selecting from past experiences here in the present. The element in the series of action during self-observation is aimed at their bodies, which presents a different type of difficulty. The function of training is to ensure that the athlete learns the forms of movement in the given sports discipline perfectly and is capable of faultlessly reproducing it, meaning that execution requires a condensation and confirmation of the context of meaning, with the objective of facilitating recall. A key element of this process, for example, is overcoming and enduring pain, pushing its limits outward. In a way, the athlete has to learn not to reflect on the signals sent by the body. The athlete has to be able to limit the sensory activities of the consciousness, a limitation process that the communication between coach and athlete also expects. The athlete signals that the verbal communication of the coach has been understood by executing the given movement. Sensory activity is aimed at reproduction. The need for modification again originates from the coach. Interviewees actually have to observe their own bodies contrary to the functional rules of the system, but in reflection of the expectations of the system.

In light of the place occupied by the athlete in the system, the role of secondary observer can also be considered to be an unusual response, yet this is not a forbidden activity. Coaches exploit the functional characteristic of the system, by resigning the possibility of unilateral control, by supposing the existence of an opposite control: observation of the observer. To ensure efficient functioning in sports, the observer's role is played by the coach: besides being responsible for ensuring that the athlete learns the regulated sports movements, applying training methods aimed at improving performance, the coach also has a controlling role. The coach does not only 'see on the pitch' - as they 
say for players - but also in the training hall. As athletes, the interviewees do nothing but try to discover, to see what their coaches are not able to see. To do this they do not step outside the system, but instead try to find a perspective from the inside, from which they can discover the things that are in the blind spots of their coaches. Interviewees observe what their coaches do not observe, what they exclude from the scope of their observation. They concentrate on those areas excluded by their coaches that belong to the system but are as yet untagged.

"How a coach becomes a coach, it depends on how the coach can observe certain things among the fellow competitors, how the coach can judge whether he/she is executing what he/she is executing correctly, how many mistakes he/she can discover in others and how he/she can correct the mistakes also occurring in his/her case."

"During the training sessions I invented new elements for the uneven bars and the balance beam or I put together the series of elements in a different order. I composed the routines to music, more in a dance style, despite the fact that back then we performed the routines without music."

“Coach - I said once before starting - I will try to cut one stroke on every lap, that way I have 250 fewer arm movements. You do what you want! - came the reply. A few months later, to make things more varied, every $5^{\text {th }}$ lap I swam was stronger. By doing this I improved 5 seconds on every hundred and finished almost five minutes earlier. I had no clue that back then a foreign athletic coach was already calling this the 'fartlektraining,."

In the case of both types of observation, the final result will be the reduction in the scope of the repertoire of movement, the aspects taken into account during execution: they highlight one element and direct their attention to that. They review the network of links of this moment and if required they change it. Based on the rules of the given sports discipline they compose new lines of action, thereby contributing to the self-development, the autopoiesis of their bodies and of the sports system. The personality will develop too, because there is body-awareness content and new interpretation behind the differing nature of movement execution. The knowledge of female coaches about their bodies - following the reduction of what has been observed - become more complex. Instead of the movement technique supposed to be ideal, they develop an individual perfection with the help of self-reflection. Doing this, they manage on the one hand to solve an unstable situation by achieving autonomy within the system, the sports discipline, because they show new, independent modes of action, while on the other hand they strengthen their personalities by successfully delivering on the expectations.

\section{Generalizing the approach}

It is not only the athletic identity of female coaches that grows in strength as a result of the process described above, but also the recognition of the ability to observe opens a new path of development to them: the coach's career. Generalization of individual experiences occurs on the level of the sports system, when female athletes become official observers, become coaches. The difference between the approach and thinking of competitors and coaches is well-characterized by the example of one of the coaches, who at the beginning of her career would rise up from the bench in critical situations and "reposition" herself as a player, trying to find a vantage point along the sidelines, which was similar to her position on the pitch during her active career. Lacking the necessary practice, it was easier for her to see the field in a more purposeful and efficient way by stepping back from the new, uncertain role into the safer past, rich in experience. She was looking for a vantage point from which 
she could recall the sensual perceptions of the player, which still functioned better and more comprehensibly than the new.

Their own way, the product of their creativity will only become a model to be followed once the elements they can apply to their athletes can be marked following a repeated reduction. The autopoiesis so important for the future of the system can only come about if they repeat this differentiation again: they do not only want to see as a coach what they saw as athletes. They do not handle this activity in an obligatory way, if they leave room for combinational opportunities. Based on the interviews I would like to highlight two areas: training methods and ideas about the ideal athlete.

“Well I really had big problems with ball-handling, because it wasn't in any of the sports [I pursued earlier]. This was a novelty, I was really clumsy handling the ball, but taking into account that this was the most difficult, this was what I taught my team best. [...] I never wanted to kill improvisation skills. I gave them a set of technical skills and rough guidelines for the match, but they always had improvisation in them."

"I invented this thing, something that I have my girls do intensively to this day, because I know it did me good, but the problem is that I forgot to acknowledge that the years have gone by and that there are certain things you cannot force, because you increase the risk of injury."

One of the main areas of research in contemporary sports science is the area of selection, talent scouting, talent nurturing. Since researchers and the institutions also form part of the system, it is natural that they should deal with questions that are outstandingly important for the functioning, the performance of the system. As a result of the life experiences of coaches, not only do they relate differently to the It-body, and not only do they question the efficacy of the optimal body scheme of the given sports discipline. Learning from their own example, they cannot dissociate the biological system from the psychical one. Some simply call this a question of wanting, of will, as it figures in the excerpt above, but there are others who cite further characteristics.

"Yes, F.A., if she did not want to quit a hundred times, saying she will not be a goalkeeper, because she is left-handed and there is always a shortage of left-handed strikers, she always wanted to be out in the field, saying she will play in the field. Her hands and feet kept getting entangled; she had that type of a body. Oh, how many times I had to push her back! She got mad at me, didn't show up for training. And who turned out to be right? Nowadays she is all grins when she sees me."

"T.Á, you might have heard her name. She was so small and so knock-kneed when called to the national youth team, but you know I never sent anyone away, so there she was and another one like her. He ran like a duck. It was a horrible sight. But you see Á. had this huge will, an intelligent kid, with good eyes and good hands, but truth be said bad footwork, but she found her position easily, used her brains, her hands and technique. What I'm saying is that if you only looked at talent, you surely would never have selected her for the national team. This is why I say, that I never liked selection. People get selected."

Once confronted with their non-compliance, female coaches increase the sensory performance of their consciousness by directing their attention elsewhere, by focusing on something else. They discover new areas, they acquire new consciousness content. However, this knowledge will only become part of the system if it can be communicated. Sometimes we are unable to verbally express things that our consciousness has sensed strongly, part of what we know remains ours, however much we would like to pass on this knowledge to others. When female coaches talk about the unique nature 
of their sensory perception, the peculiarity of their concentrated attention, they are aware of the fact that this is their one strength, the ability to which they owe a lot during their careers. Just as they cannot verbally express the entirety of their knowledge, they are unable to express entirely in words the functioning of this ability. Being confronted with the limited transparency of their consciousness, they usually use two words: luck and instinct.

"It is impossible to do it instinctively [any other way] at a high level. You have to be born for it. I don't know, I see something but only in my profession, I know immediately what is good and what isn't. I don't know, others don't even see it, I do and I myself cannot say why I see this or that thing the way I do, it is simply natural for me this way."

\section{Conclusions}

In this study I have attempted to analyse in a novel way the correlation of body awareness and self awareness in sports. To this end I have started out by using the results of (sports) psychology and (sports) sociology so far, but as a theoretical framework I relied on the theory of Luhmann on the functioning of social systems. The system-level approach when analysing the narrative life interviews conducted with female coaches was useful, because the stories they told were nothing but the answers given to the expectations of sports as a social system. As athletes their struggle for recognition is a communication with the system: continuous confirmation, because their bodies are different from what is considered to be ideal in the given sports discipline, thus not necessarily making them predestined for victory. The interviewees exploit the characteristics of the system, according to which the forms of movement related to the given sports discipline do not only mean an obligation of learning and reproduction but also provide opportunities. The stability of the system, its ability to develop are not provided by the forms, but by the movement used as a medium in communication, because opportunities for innovation lie in its elements and the way they are linked together. Observing their own movement and that of their fellow competitors, they discover opportunities that their coaches do not see. They develop their sense of perception, the most important ability of the consciousness when, by focusing their attention, they discover new structural links. In accordance with the expectations of the system they select an element from their repertoire of movement and use this consciousness in a new way. They detach themselves from traditions which observe rules and give reason to modes of action that were not used till then. This added value in thought contributes to the development of both social systems - sports and the individual. Their athletic experiences have an impact on their work as coaches as well, although they can only communicate and make it possible for others to experience a part of their knowledge. The consciousness, as a complex system, will never be able to traverse and communicate itself in its entire complexity.

\section{REFERENCES}

Andrews, D. L., Mason, D. S., Silk, M. L. (Eds.) (2005). Qualitative methods in sports studies. New York: Berg. Bahtyin, M. (1982). Francois Rabelais müvészete, a középkor és a reneszánsz népi kultúrája. Budapest: Európa.

Bodnár, I. (2003). A nők és az edzői pálya avagy a nőket megedzik. In Pető Andrea (szerk.) Társadalmi nemek képe és emlékezet Magyarországon a 19-20. században. Budapest: Nők a Valódi Esélyegyenlőségért Alapítvány, 221-245.

Bodnár, I. (2006). Sikeres edzőnők pályaválasztásának és pályakezdésének elemzése. Kalokagathia, 44. (1-2): 106-116.

Bourdieu, P. (1978). Hevenyészett megjegyzések a test társadalmi észlelésérỏl. In Bourdieu, P. A társadalmi egyenlötlenségek újratermelödése. Budapest: Gondolat, 151-164. 
Buber, M. (1991). Én és Te. Budapest: Európa.

Eichberg, H. (1994). The narrative, the situational, the biographical. Scandinavian sociology of body culture trying third way. Review for Sociology of Sport, 29. (1): 99-113.

Eichberg, H. (1995). Problems and future research in sports sociology: A revolution of body culture? Review for Sociology of Sport, 30. (1): 1-17.

Foucault, M. (1990). Felügyelet és büntetés. Budapest: Gondolat.

Giddens, A. (1991). Modernity and self-identity. Self and society in the late modern age. Cambridge: Polity Press

Giulianotti, R. (2005). Sport: A critical sociology. Cambridge: Polity Press.

Harsányi, L. (2000). Edzéstudomány. I. köt. Budapest - Pécs: Dialóg Campus.

Kende, A. (2002). Testazonosság és identitás. A különböző testfelfogások szerepe az önelfogadásban. In: Csabai Márta - Erős Ferenc (szerk.) Test-beszédek. Budapest: Új Mandátum Könyvkiadó. 61-83.

Kudar, K. (1994). Az egyes testrészek és testtájak tudatossági szintje a testképben, és ezek személyiségtulajdonságokkal való összefüggésének vizsgálata férfi sportolókon. Kandidátusi értekezés. Budapest: MTA.

Luhmann, N. (1995). Social system. Stanford: Stanford University Press.

Luhmann, N. (1999). Látom azt, amit te nem látsz. Budapest: Osiris.

Luhmann, N. (2006). Bevezetés a rendszerelméletbe. Budapest: Gondolat.

Schilder, P. (1978). The image and appearance of the human body. Oxford: Blackwell.

Shogan, D. (1999). The making of high-performance athletes: Discipline, diversity, and ethics. Toronto: University of Toronto Press.

Szántó, Z. (2006). A strukturális kiegyensúlyozottság elmélete. In Szántó Z. Analitikus szemléletmódok a modern társadalomtudományban. Budapest: Helikon, 159-170.

Tangen, J. O. (2004). Embedded expectations, embodied knowledge and the movements that connect. A system theoretical attempt to explain the use and non-use of sport facilities. Review for Sociology of Sport, 39. (1): 7-25. 